\title{
Microplastics in Muskoka-Haliburton Headwater Lakes, Ontario, Canada
}

Brittany Welsh ( $\square$ brittanywelsh@trentu.ca )

Trent University https://orcid.org/0000-0003-1351-7570

Julian Aherne

Trent University

Andrew M Paterson

Dorset Environmental Science Centre

Huaxia Yao

Dorset Environmental Science Centre

Chris McConnell

Dorset Environmental Science Centre

\section{Research Article}

Keywords: Plastic pollution, microfibres, temporal variability, sediment, depth samples

Posted Date: January 27th, 2022

DOI: https://doi.org/10.21203/rs.3.rs-1181662/v1

License: (c) (i) This work is licensed under a Creative Commons Attribution 4.0 International License.

Read Full License 
Microplastics in Muskoka-Haliburton headwater lakes, Ontario, Canada

\section{Author information}

Brittany Welsh ${ }^{a}$, Julian Aherne ${ }^{a}$, Andrew M. Paterson ${ }^{b}$, Huaxia Yao ${ }^{b}$, and Chris McConnell ${ }^{b}$

${ }^{\text {a }}$ School of the Environment, Trent University, Peterborough, Ontario, K9L 0G2, Canada

${ }^{\mathrm{b}}$ Ministry of the Environment, Conservation and Parks, Dorset Environmental Science Centre, Dorset,

8 Ontario POA 1EO, Canada

$9 \quad$ Corresponding author: Brittany Welsh. E-mail: brittanywelsh@trentu.ca

Microplastics ( $\mathrm{mp}$ ) are a growing environmental concern due to their ubiquity in terrestrial and aquatic environments. Nonetheless, there is limited knowledge on their abundance in lakes in rural areas. In this study, we surveyed 14 headwater lakes in Muskoka-Haliburton, Ontario, to assess the spatial and temporal variability of microplastics. The average microplastic concentration across the study lakes was $1.78 \mathrm{mp} / \mathrm{L}$ during May-June 2019, with limited spatial variability (coefficient of variation $=22 \%$ ). Further, microplastic abundance was weakly correlated with lake area (rs: 0.469), the number of shoreline residences (rs: 0.399), and watershed area (rs: 0.350), suggesting that diffusive inputs, such as atmospheric deposition, were the dominant source of microplastics to the study lakes. In contrast, microplastics showed a distinct temporal (seasonal) variability, as the average concentration in August 2019 (0.91 mp/L) was significantly lower $(\mathrm{p}<0.05)$ compared with May and June 2019. While microplastic abundance was generally higher in the metalimnion $(0.70 \mathrm{mp} / \mathrm{L})$ and epilimnion $(0.67 \mathrm{mp} / \mathrm{L})$, there was no significant difference by stratified layer. The annual percent removal of microplastics in lake sediment was estimated to be $14 \%$, suggesting that for most of the study lakes, sediment burial was not a dominant sink for microplastics. Effective management of microplastic pollution requires an understanding of the interlinkages between microplastics in the atmosphere, lake water, and sediment. In rural areas, microplastic abundance appears to be dominated by atmospheric inputs, suggesting limited need for spatial monitoring. Temporal monitoring however is required to understand seasonal changes and longterm trends in microplastic abundance and delivery.

\section{Keywords}

30 Plastic pollution, microfibres, temporal variability, sediment, depth samples

\section{Acknowledgements}

The authors would like to thank members of the Ministry of the Environment, Conservation and Parks, especially Ron Ingram, and summer co-op students at the Dorset Environmental Science Centre, for routinely collecting lakes samples for analysis as well as Tim Field for providing additional background information on the study sites. The authors would also like to thank Jill Crossman for facilitating access to micro-Raman spectroscopy in the Great Lakes Institute for Environmental Research at the University of Windsor. 


\section{Introduction}

The mass production of plastic materials coupled with the mismanagement of waste has led to an international plastic crisis (Cole et al. 2011; Li et al. 2018). Consequently, large quantities of plastic waste exist in the environment with microplastics becoming ubiquitous and pervasive. Microplastics, particles less than $5 \mathrm{~mm}$ in size, are either manufactured to be microscopic in size (primary microplastics) or arise through the fragmentation of larger plastic pieces (secondary microplastics) via biological degradation, mechanical transformation, and photodegradation (Cole et al. 2011; Lebreton et al. 2018; Sa et al. 2018). Microplastics can originate from a variety of sources such as textiles, cleaning products, tire wear particles, cosmetic and personal care products and can enter the environment through a number of different pathways including effluent from wastewater treatment plants, atmospheric deposition, road wear suspension, and storm-water run-off (ECCC 2020; Kallenbach et al. 2021; Triebskorn et al. 2019; Lenaker et al. 2019).

Microplastics are of widespread concern due to the potential risks they pose to organisms (Wright et al. 2013; Sussarellu et al. 2016). Microplastics have a tendency to be ingested by all levels of the food web, with studies reporting on microplastic ingestion in invertebrates, fish, turtles, birds, and mammals (Li et al. 2018; Kallenbach et al. 2021; Duncan et al. 2018, Carlin et al. 2020; Di Renzo et al. 2021). Furthermore, microplastics contain chemical additives (e.g., antimicrobials, phthalates, flame retardants, dyes, etc.), many of which are toxic, and they can potentially adsorb and accumulate toxic compounds, such as trace and heavy metals, pathogens, pharmaceuticals, and persistent organic pollutants (Hirai et al. 2011; Mato et al. 2011; Rochman et al. 2014; Remy et al. 2015). The ingestion of microplastics and their associated chemicals can result in the uptake and accumulation of toxic compounds, clogging or obstruction of feeding appendages and/or the digestive system, oxidative stress, reproductive disruption, carcinogenesis, neurotoxicity and in some cases death (Kallenbach et al. 2021; Gomes et al. 2021; Li et al. 2018; Baldwin et al. 2016; Sussarellu et al 2016).

Studies on microplastics have primarily concentrated on marine environments, where plastic litter conspicuously accumulates ( $\mathrm{Li}$ et al. 2018). Freshwater environments have largely been overlooked as sinks for microplastics as they were only thought to be conduits for plastics to the ocean (Hoellein and Rochman 2021). As such, very few studies have been conducted on microplastics in freshwater environments. Those that have examined freshwater rivers and lakes (e.g., Felismino et al. 2021; Lenaker et al. 2019; Anderson et al. 2017; Grbić et al. 2020) have primarily focused downstream of wastewater treatment plants or urban environments, with few studies on microplastics in rural areas distant from major anthropogenic point sources. Furthermore, very few studies have examined the spatial and temporal variability of microplastics. The objective of this study was to quantify the abundance of microplastics in headwater lakes in Muskoka-Haliburton. During summer 2019, a regional assessment of microplastics was conducted in 14 headwater lakes with water samples being collected on multiple occasions. At a subset of the study sites, lake sediment samples and water samples from each stratified layer were also collected. We specifically wanted to assess the spatial and temporal variability in microplastic abundance in small, rural lakes to understand their role in the microplastic cycle.

2. Materials and Method

77 2.1. Study Area

78 The Muskoka-Haliburton region is comprised of two adjacent municipalities in south-central Ontario, 79 Canada, the District Municipality of Muskoka, more commonly referred to as 'Muskoka', and Haliburton 
County. The region, which is located approximately 2.5 hours $(250 \mathrm{~km})$ north of Toronto, is commonly referred to as cottage country as it sees more than 2.1 million tourists and visitors each year during the summer period. The Muskoka-Haliburton region spans $8,041 \mathrm{~km}^{2}$, has a year-round population of 78,661 and contains more than 1,200 lakes. The region has a humid continental climate with a 30-year annual precipitation average of $1,008 \mathrm{~mm}$, of which $30 \%$ falls as snow (Yao et al. 2009).

\subsection{Study Sites}

The study focused on 14 small rural lakes in Muskoka-Haliburton (Figure 1; Table 1) that are part of a longterm monitoring network operated by the Ministry of the Environment, Conservation and Parks' Dorset Environmental Science Centre to assess the impacts of multiple stressors (e.g., cottage development and long-range atmospheric transport of pollutants) on aquatic ecosystems (Dillon and Molot 2005; Girard et al. 2007). All lake catchments are primarily forested. Agricultural activity is non-existent except in the vicinity of Three Mile Lake, and there is some residential development on most of the study lakes (Hall and Smol 1996; Table 1). The residences that are present are located on the shores of the lakes rather than inland and are serviced by septic systems (Hall and Smol 1996). There are several rural municipalities in the study region with seasonal recreation being the dominant form of human activity; however, the study lakes are more than $200 \mathrm{~km}$ from large urban or industrial centers (Hall and Smol 1996; Scheider et al. 1979). The lakes range from mesotrophic to oligotrophic and are single lake basins, with the exception of Red Chalk Lake and Three Mile Lake, which each have two basins (Dillon and Molot 2005; Girard et al. 2007). Samples from these lakes were collected from the main and east basin for Red Chalk Lake and from Hammell's Bay for Three Mile Lake. All lakes are headwater lakes with the exception of Red Chalk Lake which receives discharge from Blue Chalk Lake.

\subsection{Lake Water Sampling}

Lake water samples (1.0-1.5 L) were collected by the Ministry of the Environment, Conservation and Parks between May and October 2019, from the deepest point of each of the study lakes, 1-metre below the surface with replicate samples $(n=3)$ at 5 lakes (Table 1$)$. At a subset of lakes $(n=10), 1 \mathrm{~L}$ samples were also collected from the epilimnion, metalimnion and hypolimnion during August 2020 (Table 1). These samples were collected in a volume-weighted fashion from discreet depths $(1 \mathrm{~m}, 3 \mathrm{~m}, 5 \mathrm{~m}$, etc., throughout the epi-, meta-, or hypolimnion), with thermal layers determined from a temperature profile. All samples were collected using a peristaltic pump with Tygon tubing and stored in a dark refrigerator until processed.

\subsection{Sediment Sampling}

Sediment cores were collected from a subset of lakes $(n=7)$ between June and September 2019 (Table 1) with duplicate sediment cores collected at 3 lakes. The sediment cores were collected from the deepest point of each lake using a Glew gravity corer attached to a clear Lucite ${ }^{\mathrm{TM}}$ core tube with an internal diameter of $7.62 \mathrm{~cm}$. The sediment cores were extruded on shore using a Glew vertical extruder, an extruding tray and a 4-inch stainless steel paint scraper. Before extrusion, any water present on the surface of the sediment core was removed using a pipette and/or narrow plastic tubing and the first $3 \mathrm{~cm}$ of the sediment was extruded and placed into a sterile Whirl-Pak ${ }^{\circledast}$ bag. The middle section of the sediment core was discarded, and the $30-33 \mathrm{~cm}$ section of the sediment core was extruded and placed into a sterile Whirl-Pak ${ }^{\circledR}$ bag. In three of the lakes, the sediment cores were greater than $20 \mathrm{~cm}$ but less than $33 \mathrm{~cm}$, so the last $3 \mathrm{~cm}$ of the sediment core was extruded. The $30-33 \mathrm{~cm}$ section, or the last $3 \mathrm{~cm}$ of the core, corresponds temporally to the pre-industrial era, prior to the invention of plastic; a number of lakes in the study area have been dated using $\mathrm{Pb}^{210}$ and the pre-industrial era was determined to be at a depth of 
between 15 and $20 \mathrm{~cm}$ in the sediment column (Mills et al. 2009). The stainless-steel paint scraper and extruding tray were rinsed in lake water, cleaned with Kimwipes ${ }^{\mathrm{TM}}$ and rinsed three times with filtered deionized (DI) water before sectioning the upper $3 \mathrm{~cm}$ and the $30-33 \mathrm{~cm}$ section (or deepest $3 \mathrm{~cm}$ ) of each sediment core. Sediment samples were stored in a dark refrigerator until processed.

\subsection{Microplastic Extraction: Lake Water}

Samples were vacuum filtered through $1.6 \mu \mathrm{m}$ Fisherbrand ${ }^{\mathrm{TM}} \mathrm{G} 6$ glass-fibre filter papers and the filtrate was emptied into a graduated cylinder to determine the exact volume of the sample. Sample bottles were triple rinsed with either filtered B-pure ${ }^{\mathrm{TM}}$ water or filtered DI water and filtered through the same filter paper as the original sample. The filter papers were immediately transferred to petri dishes, sealed, and stored for analysis.

\subsection{Microplastic Extraction: Sediment Samples}

Sediment samples were oven dried at approximately $55^{\circ} \mathrm{C}$ for approximately 72 hours. Under a laminar flow fume hood, $3 \mathrm{~g}$ of dried sediment was digested from each sediment core following the wet peroxide oxidation method outlined in Roblin and Aherne (2020). The sample was sieved through $100 \mu \mathrm{m}$ mesh and the material remaining on the mesh was density separated in zinc chloride $\left(1.5 \mathrm{~g} / \mathrm{cm}^{3}\right)$, using an apparatus from Coppock et al. (2017). Any residual material still remaining on the mesh was rinsed with filtered B-pure ${ }^{\mathrm{TM}}$ and vacuum filtered onto a $1.6 \mu \mathrm{m}$ Fisherbrand ${ }^{\mathrm{TM}} \mathrm{G} 6$ glass-fibre filter paper. For the density separation procedure, a magnetic stir rod was added to the apparatus and the mixture was stirred at 650 RPM for five minutes, left to settle for five minutes, and pulsed three times to remove any trapped air bubbles. The mixture was left to sit for one more minute allowing the supernatant to become clear before the ball valve was closed. The top portion of the density separator was vacuum filtered through $1.6 \mu \mathrm{m}$ Fisherbrand ${ }^{\mathrm{TM}} \mathrm{G} 6$ glass-fibre filter papers and triple rinsed with filtered B-pure ${ }^{\mathrm{TM}}$ to remove any particles remaining. The bottom portion of the density separator was vacuum filtered through new glassfibre filter papers and triple rinsed with filtered B-pure ${ }^{\mathrm{TM}}$ and the filter papers were individually sealed in sterile petri dishes for microscopic analysis.

\subsection{Microplastic Identification}

Using a Leica EZ44 stereomicroscope with an EZ4W0170 camera, the filter papers were visually analyzed at 32x magnification for the presence of anthropogenic particles following the visual identification criteria and protocol widely used by Roblin et al. (2020), Roblin and Aherne (2020) and Loppi et al. (2021). The five criteria used were: (i) unnaturally coloured (blue, red, purple, etc.) relative to the sample, (ii) no visible cellular structure or offshoots and appears homogenous in texture and material; (iii) not brittle and remains intact when poked, compressed or tugged with fine tweezers; (iv) shiny or glossy appearance; and ( $v$ ) no similarities to natural fibres and has limited fraying. If two or more of the criteria were met, the particle was classified as an anthropogenic particle (i.e., synthetic but not necessarily plastic), the colour and proportion of criteria each particle met was recorded and each anthropogenic particle was photographed and measured using an image processing software (ImageJ; URL: imagej.nih.gov/ij). Particles were identified down to a size class of $50 \mu \mathrm{m}$ but smaller particles were identified where possible. The size (length) of particles were manually estimated by converting the number of pixels measured to a known length in millimetres. All non-fibres were referred to as fragments as there were few to no films or foams identified; see Supporting Information (Section A) for further details on the size, shape, and colour of anthropogenic particles. A minimum of $20 \%$ of the anthropogenic particles were randomly selected and tested using the hot needle test to determine the proportion that were plastic (i.e., polymers with a 
petrochemical base). Following Roblin et al. (2020) and Hidalgo-Ruz et al. (2012), a hot needle was pressed against the edge of the selected particle and if the particle melted, it was classified as plastic. Within the lake water and sediment samples, the proportion of plastic (i.e., the proportion of anthropogenic particles that melted) were used to report the number of microplastics.

\subsection{Raman Spectroscopy}

Similar to Loppi et al. (2021), micro-Raman spectroscopy (WITec, operated by WITec Control) was used to characterize the polymer type of the plastic particles. Fibres were analyzed using $785 \mathrm{~nm}$ laser and fragments were analyzed using $532 \mathrm{~nm}$ laser at 100x objective and adjustable power (ranging from $0 \mathrm{~mW}$ to approximately $85 \mathrm{~mW}$ ). To confirm polymer identity, spectra were recorded in $0-1800 \mathrm{~cm}^{-1}$ wavelength and analyzed through a commercial library (Open Specy; Cowger et al. 2021; Figure SI-2).

\subsection{Quality Control and Assurance}

This study was built onto an existing long-term monitoring program that routinely used plastic containers for collection. To determine potential contamination, lake blanks $(n=12)$ were collected in the field using filtered B-pure ${ }^{\mathrm{TM}}$ or DI water with the routine sample containers; plastic particles were not identified in the lake blanks. Furthermore, procedural open-air blanks, i.e., open petri dishes with filter papers, were routinely collected and used to determine potential contamination during the extraction and analysis process in the laboratory. Open-air blanks were exposed during filtering and particle identification and the period of exposure was recorded. The average potential contamination was less than one microplastic per sample based on the average contamination from the open-air blanks and the time samples were exposed to the air (Table 2). Accordingly, samples were not blank corrected as potential contamination was low. Procedural B-pure ${ }^{\mathrm{TM}}$ water, DI water, zinc chloride and hydrogen peroxide blanks were also collected by vacuum filtering a known quantity through $1.6 \mu \mathrm{m}$ Fisherbrand ${ }^{\mathrm{TM}} \mathrm{G} 6$ glass-fibre filter papers and analyzing them following the same method as the field samples (Table 2). The average potential contamination in these blanks ranged from $0.16 \mathrm{mp} / \mathrm{L}$ to $7.38 \mathrm{mp} / \mathrm{L}$, therefore, all solutions (i.e., DI water, B-pure $^{\mathrm{TM}}$ water, zinc chloride, hydrogen peroxide) were vacuum filtered prior to use in the Fe (II) solution, sediment digestion, density separation, rinsing and cleaning to prevent or limit potential contamination.

Approximately 21 microplastics were identified in the blanks, nine were found in solutions prior to filtration (i.e., all solutions were filtered prior to use), 11 were found in open air blanks with an average exposure of 6.5 hours and one was found in a microscope blank with an average exposure of 42 hours. The field samples had an average exposure of 0.60 hours during the filtering process and 0.17 hours during microscope analysis. Although some plastic was used during the sample procedure, i.e., the sample bottles were comprised of polyethylene terephthalate, the petri dishes and weigh boats were comprised of polystyrene, and the Whirl-Pak ${ }^{\oplus}$ bags were comprised of polyethylene, potential contamination was limited. There were no microplastics identified in the lake field blanks $(n=12)$ and the polystyrene, polyethylene and polyethylene terephthalate polymers identified in the field samples were coloured indicating that they did not originate from laboratory sources. In addition, all equipment was triple rinsed with filtered B-pure ${ }^{\mathrm{TM}}$ or filtered DI water prior to use and immediately covered in aluminium foil when not in use. The Buchner funnel was triple rinsed with filtered B-pure ${ }^{\mathrm{TM}}$ or filtered DI water, cleaned with Kimwipes $^{\text {TM }}$ to remove any remaining material, and triple rinsed again in between each sample. Finally, all samples were collected, processed and analyzed using nitrile gloves and $100 \%$ cotton laboratory coats were worn when processing and analyzing the samples. 
The concentration of microplastics in lake water is reported as the number of microplastics per litre $(\mathrm{mp} / \mathrm{L})$ and for sediment as the number of microplastics per gram of dried sediment $(\mathrm{mp} / \mathrm{g})$. For the lake water samples collected 1-metre below the surface between May and June 2019, the average concentration of microplastics in the lake was multiplied by the total lake volume to determine the total number of microplastics in the lake. A Spearman's correlation test was used to determine the association between the average microplastic concentration and lake attributes (number of shoreline residences, lake area, watershed area, mean depth and max depth; Table 1$)$. The variability between replicate $(n=3)$ lake water samples was determined as the coefficient of variation. For the temporal samples collected between May and October 2019, the average concentration of microplastics was determined for each month by lake. The concentration of microplastics in the epilimnion, metalimnion and hypolimnion for each lake was calculated and multiplied by the percent of the total lake volume that each stratum comprised to determine the volume-weighted concentration of microplastics. Statistical comparisons between temporal periods or lake strata were generally based on a paired T-test or repeated-measures ANOVA with Tukey's pairwise test carried out in Past 4.06b (Hammer et al. 2001).

The concentration of microplastics $(\mathrm{mp} / \mathrm{g}$ ) in each sediment core section was calculated and the average microplastic concentration was determined for duplicate cores. The average variability between duplicate sediment samples was based on their relative percent difference. As individual cores were not dated, the average sedimentation rate for lakes in Muskoka-Haliburton (Mills et al. 2009) and microplastic concentration was used to determine a rough microplastic accumulation rate $\left(\mathrm{mp} / \mathrm{m}^{2} /\right.$ day) in the top section of the sediment core for each lake. The percent of microplastics that are removed annually via sedimentation was determined using the microplastic accumulation rate, lake area and total number of microplastics in the lake. A Spearman's correlation test was then used to determine if there was a correlation between the average microplastic concentration and lake attributes (number of shoreline residences, lake area, watershed area, mean depth and max depth).

\section{Results and Discussion}

\subsection{Spatial and Temporal Variability in Microplastic Concentration} The concentration of microplastics in the study lakes $(n=12)$ ranged from 1.02-2.39 mp/L between May and June 2019 with an average concentration of $1.78 \mathrm{mp} / \mathrm{L}$ (Table 3; Table SI-5); microplastics were normally distributed across the lakes (Figure 2) with a coefficient of variation of $22 \%$. The average coefficient of variation for replicate samples $(n=3)$ was generally consistent across the study lakes at $53 \%$. When lake volume was taken into account, the total number of microplastics in lakes across the region ranged from 0.45 billion to 34.59 billion microplastics, with an average of 8.18 billion microplastics per lake, and a coefficient of variation of $115 \%$.

The abundance of microplastic $(\mathrm{mp} / \mathrm{L}$ ) in the study lakes was weakly correlated with lake area ( $\mathrm{rs}: 0.469)$, the number of shoreline residences (rs: 0.399), and watershed area (rs: 0.350). Given the low variability in the concentration of microplastics between lakes (coefficient of variation of $22 \%$ ), this suggests that diffuse inputs such as atmospheric deposition, which is influenced by lake and catchment size, was the dominant source of microplastics to the study lakes. While the number of shoreline residences may be an indicator of direct anthropogenic inputs, the number of residences is also correlated to lake size, which is the likely association in the study lakes given the weaker correlation to microplastic abundance. Furthermore, lakes which had very few or no residences (see Table 1) and consequently limited road 
access, had similar microplastic concentrations compared with lakes that had numerous homes and cottages and year-round road access (Table SI-5). This further suggests that atmospheric deposition is likely the dominant source of microplastics to the study region and is an important vector in the transport of microplastics to remote or rural regions. Several studies have observed that microplastics found in remote areas such as the Arctic, French Pyrenees Mountain, Atlantic coastline, the Alps and Muskoka, are linked to atmospheric deposition (Bergmann et al. 2019; Allen et al. 2019; Ambrosini et al. 2019; Roblin et al. 2020; Welsh 2022). Furthermore, the concentration of microplastics detected in atmospheric deposition in the French Pyrenees mountain, a remote site with no development within $95 \mathrm{~km}$, was comparable to microplastic concentrations in atmospheric deposition in large cities (Allen et al. 2019; Dris et al. 2016; Cai et al. 2017; Wright et al. 2020).

The average concentration of microplastics in the lake samples collected between May and October from the study lakes $(n=9)$ ranged from 0.91 to $2.09 \mathrm{mp} / \mathrm{L}$, with the highest concentration generally being observed between May and June (Figure 3a; Table SI-6). The average monthly microplastic abundance was significantly lower in August compared with May and June $2019(p<0.05)$. Further, the average microplastic abundance during May-June 2019 in the study lakes $(n=9)$ was significantly greater than the six-month (May-October 2019) average abundance (1.43 mp/L; $p<0.05)$, suggesting a distinct seasonal variability (Figure $3 \mathrm{~b}$ ). There was no significant difference in the abundance of microplastics between lakes during May to October 2019, except for Chub Lake, which had a significantly higher abundance compared with Harp (Figure $3 c ; p<0.05$ ).

Comparing the concentration of microplastics in lakes across published studies can be difficult due to differences in sampling methodologies; net or trawl versus pump, mesh size, sample depth, identification techniques (visual identification, FT-IR, Raman, size class) as well as the use of different units ( $\mathrm{mp} / \mathrm{L}$, $\mathrm{mp} / \mathrm{km}^{2}, \mathrm{mp} / \mathrm{m}^{3}$ ) for reporting microplastics concentration (ECCC 2020; Dusaucy et al. 2021). The average concentration of microplastics in the study lakes during May-June $(1.78 \mathrm{mp} / \mathrm{L})$ was much higher than the concentration of microplastics observed in Lake Simcoe $(0.4 \mathrm{mp} / \mathrm{L})$ and the concentration of particles in Lake Ontario, near Toronto (0.8 particle/L), both of which are urbanized lakes (Felismino et al. 2021; Grbić et al. 2020). The average microplastic concentration in the study lakes, however, is generally consistent with stream samples collected from Mount Everest during April and May 2019, which ranged from 0-2 $\mathrm{mp} / \mathrm{L}$ with an average concentration of $1 \mathrm{mp} / \mathrm{L}$ (Napper et al. 2020).

\subsection{Variability in Microplastic Concentration with Depth}

Across the stratified layers, there was no significant difference in the concentration of microplastics, but generally higher concentrations were observed in the upper layers (Figure 4a; Table SI-7). The average microplastic concentration in the epilimnion and metalimnion was $0.67 \mathrm{mp} / \mathrm{L}$ and $0.70 \mathrm{mp} / \mathrm{L}$, respectively, compared with $0.53 \mathrm{mp} / \mathrm{L}$ in the hypolimnion. Further, the coefficient of variations for microplastics was greater in the metalimnion (63\%) compared with the epilimnion (33\%) and hypolimnion (51\%) potentially suggesting a slight preferential settling of microplastics within the study lakes based on plastic type (fibre versus fragment) or density.

284 The average volume-weighted microplastic concentration $(0.66 \mathrm{mp} / \mathrm{L})$ was very similar to the 285 concentration in samples collected at a depth of $1-\mathrm{m}(0.68 \mathrm{mp} / \mathrm{L})$, suggesting that a 1-m depth sample is representative of the concentration of microplastics in the lake, although the 1-m samples showed greater variability between lakes ( $49 \%$ versus $26 \%$; Figure $4 \mathrm{~b}$ ). It is worth noting that the abundance of 
microplastics in the study lakes was significantly lower $(p<0.05)$ in August 2020 compared with August 2019, again high lighting the importance of capturing temporal observations (Figure 4c; Table SI-8).

290

291

292

293

294

295

296

297

298

299

300

301

302

303

304

305

306

307

308

309

310

311

312

313

314

315

316

317

318

319

320

321

322

323

324

325

326

327

The lack of a distinct vertical distribution in the concentration of microplastics in the study lakes is similar to Tamminga and Fischer (2020), who examined a dimictic lake in northern Germany and found that the concentration of fibres did not display a noticeable vertical distribution. They did, however, find that the concentration of irregular particles displayed a distinct vertical pattern, decreasing with depth, but this vertical difference was not significant (Tamminga and Fischer 2020). Similarly, Lenaker et al. (2019) found that the concentration of microplastics at five out of the six river and lake sites, were not significantly different between the surface and subsurface.

\subsection{Sediment}

In the top 0-3 cm section, the concentration of microplastics ranged from 2.17 to $5.45 \mathrm{mp} / \mathrm{g}$ with an average of $3.66 \mathrm{mp} / \mathrm{g}$ and a coefficient of variation of 35\% (Figure 5; Table SI-9).

There was a weak correlation between the concentration of microplastics in the top $0-3 \mathrm{~cm}$ section and the number of cottages on the lake ( $r s: 0.487$ ). In the bottom section of the sediment core, the abundance of microplastics was significantly lower $(p<0.05)$ than the top section, with an average concentration of $0.72 \mathrm{mp} / \mathrm{g}$ and a coefficient of variation of $47 \%$. The presence of microplastics in the bottom $30-33 \mathrm{~cm}$ section of the sediment core, which corresponds temporally to the pre-industrial era, suggests that microplastics can migrate or mobilize down the sediment column.

The average relative percent difference between duplicate cores $(n=3)$ for the top $0-3 \mathrm{~cm}$ section was $20 \%$ and for the bottom $30-33 \mathrm{~cm}$ section it was $42 \%$, suggesting slightly higher variability in microplastics abundance in sediment between the lakes than between duplicate cores. Furthermore, the bottom section of the sediment core had greater variability in microplastic abundance compared to the top. Given an average rate of sedimentation for the study lakes (Mills et al. 2009), the average accumulation of microplastics in the top lake sediment was $1.78 \mathrm{mp} / \mathrm{m}^{2} /$ day $\left(1.06-2.65 \mathrm{mp} / \mathrm{m}^{2} /\right.$ day) with a coefficient of variation of $34 \%$. As such, the percent of microplastics buried annually into the lake sediment ranged from 1.1-63.6\% with an average of $14 \%$ and a median of 5.3\%. This suggests that for most lakes (Table SI-9), lake sediment is a small sink for microplastics with the majority of microplastics leaving the lake via the outflow.

The concentration of microplastics in the top section of the sediment core for the study lakes $(2,170-$ $5,450 \mathrm{mp} / \mathrm{kg}$ ) is much higher than the concentration of microplastics in sediment observed in urban lakes such as Lake Simcoe (1.24-160 mp/kg), Lake Erie (0-391 mp/kg), Lake Ontario (40-4,270 mp/kg) and lakes located in Lake Mead National Recreation Area (87.5-1,010 mp/kg) (Felismino et al. 2021; Dean et al. 2018; Ballent et al. 2016; Baldwin et al. 2020). This is likely due to methodological differences as these studies used a Petite Ponar to collect surficial sediment samples. If the concentration of microplastics in the $0-3 \mathrm{~cm}$ section and $30-33 \mathrm{~cm}$ section of the study lakes is averaged (Table SI-5), the range is reduced to $1,730-3,220 \mathrm{mp} / \mathrm{g}$ but it is still higher than observations from other studies. The decrease in microplastic abundance with sediment depth is similar to Turner et al. (2019) who collected a sediment core from an urban lake in London, UK; in their study, the concentration of microplastics in the $0-5 \mathrm{~cm}$ section was 539 particles $/ \mathrm{kg}$ and decreased to a concentration of 78.2 particles $/ \mathrm{kg}$ at a depth of 30-35 $\mathrm{cm}$. 


\subsection{Microplastic Characterization}

In the lake water and bottom section of the sediment core, fibres were the dominant anthropogenic particle shape identified (>70\%) whereas in the top section of the sediment core, fibres were only slightly more common than fragments (57\%; see Supporting Information Section A). There was no noticeable difference in the proportion of fibres and fragments across the lakes depths with fibres being relatively evenly distributed (51-67\%).

Of the anthropogenic particles that were identified in the lake samples and tested using a hot needle, $14 \%$ melted and were identified as plastic. In the lake sediment, $36 \%$ of the anthropogenic particles identified in the top $0-3 \mathrm{~cm}$ section melted while only $13 \%$ in the bottom $30-33 \mathrm{~cm}$ section melted. Thermoplastics were the predominant plastic type identified in the study lakes with polypropylene being most abundant (26\%) followed by acrylonitrile butadiene styrene $(21 \%)$ and polyethylene (16\%). In the lake samples, there was an equal proportion (22\%) of polypropylene, polyethylene and polyisoprene identified with polyamide, polyacrylamide and polyethylene terephthalate also being identified. In the lake sediment, the majority of particles were acrylonitrile butadiene (40\%) followed by polypropylene (30\%). Polyamide, polyethylene, and styrene acrylonitrile were also identified but were less common.

\section{Conclusion}

There was limited spatial variability in the concentration of microplastics across the study lakes with microplastic abundance being weakly correlated with lake area (rs: 0.469), the number of shoreline residences (rs: 0.399), and watershed area (rs: 0.350). This suggests that atmospheric deposition is the dominant source of microplastics to the study lakes, and therefore, limited spatial monitoring can adequately quantify microplastic abundance in headwater catchments in rural regions. In contrast, temporal monitoring is required as a distinct seasonal variability in microplastics abundance was observed, with August 2019 having a significantly lower concentration compared with May and June 2019. This suggests that seasonal changes in diffuse sources or hydrological processes influence the abundance of microplastics within headwater lakes in rural areas.

Sediment has been identified as an important long-term sink for microplastics in freshwater environments; however, in this study, the percent of microplastics buried in the lake sediment annually was relatively low. This suggests that lake sediment is not a dominant sink for microplastics, but rather that small rural lakes are reservoirs for export to downstream rivers or lakes. Few studies, however, have evaluated the residence time of microplastics in lakes, which is an important factor in the microplastic cycle as it identifies the length of time microplastics can stay (reside) in a lake. Future monitoring and research in rural lakes should focus on a catchment balance approach for microplastics, including atmospheric inputs, in order to better understand the fluxes and cycle of microplastics in lakes. This will help to improve our understanding on microplastics and will allow for effective policy decisions to address microplastic pollution. 


\section{References}

Allen S, Allen D, Phoenix VR, Le Roux G, Durántez Jiménez P, Simonneau A, Binet S, Galop D (2019) Atmospheric transport and deposition of microplastics in a remote mountain catchment. Nat Geosci 12:339-344

Ambrosini R, Azzoni RS, Pittino F, Diolaiuti G, Franzetti A, Parolini M (2019) First evidence of microplastic contamination in the supraglacial debris of an alpine glacier. Environ Pollut 253:297-301

Anderson PJ, Warrack S, Langen V, Challis JK, Hanson ML, Rennie D (2017) Microplastic contamination in Lake Winnipeg, Canada. Environ Pollut 225:223-231

Baldwin AK, Corsi SR, Mason SA (2016) Plastic debris in 29 Great Lake tributaries: Relations to watershed attributes and hydrology. Environ Sci Technol 50:10377-10385

Baldwin AK, Spanjer AR, Rosen MR, Thom T (2020) Microplastics in Lake Mead National Recreation Area, USA: Occurrence and biological uptake. PLOS ONE 15:1-20

Ballent A, Corcoran PL, Madden O, Helm PA, Longstaffe FJ (2016) Sources and sinks of microplastics in Canadian Lake Ontario nearshore, tributary and beach sediments. Mar Pollut Bull 110:383-395

Bergmann M, Mutzel S, Primple S, Tekman MB, Trachsel J, Gerdts G (2019) White and wonderful? Microplastics prevail in snow from the Alps to the Arctic. Sci Adv 5:1-10

Cai L, Wang J, Peng J, Tan Z, Zhan Z, Tan X, Chen Q (2017) Characteristics of microplastics in the atmospheric fallout from Dongguan city, China: Preliminary research and first evidence. Environ Sci Pollut Res 24:24928-24935

Carlin J, Craig C, Little S, Donnelly M, Fox D, Zhai L, Walters L (2020) Microplastic accumulation in the gastrointestinal tracts in birds of prey in central Florida, USA. Environ Pollut. 264:114633

Cole M, Lindeque P, Halsband C, Galloway TS (2011) Microplastics as contaminants in the marine environment: A review. Mar Pollut Bull 62:2588-2597

Coppock RL, Cole M, Lindeque PK, Queiros AM, Galloway TS (2017) A small-scale, portable method for extracting microplastics from marine sediment. Environ Pollut 230:829-837

Cowger W, Steinmetz Z, Gray A, Munno K, Lynch J, Hapich H, ..., Herodotou O (2021) Microplastic spectral classification needs an open source community: Open Specy to the rescue! Anal Chem 93:7543-7548

Dean BY, Corcoran PL, Helm PA (2018) Factors influencing microplastic abundances in nearshore, tributary and beach sediments along the Ontario shoreline of Lake Erie. J Great Lake Res 44:10021009

Di Renzo L, Mascilongo G, Berti M, Bogdanović T, Brkljača M, Notarstefano V et al (2021) Potential impacts of microplastics and additives on the health status of loggerhead turtles (Caretta caretta) stranded along the Central Adriatic Coast. Water Air Soil Pollut 232:98-118

Dillon PJ, Molot LA (2005) Long-term trends in catchment export and lake retention of dissolved organic carbon, dissolved organic nitrogen, total iron, and total phosphorus: The Dorset, Ontario, study, 1978-1998. J Geophys Res Biogeo 110:1-7 
Dris R, Gasperi J, Mirande C, Tassin B (2016) Synthetic fibres in atmospheric fallout: A source of microplastics in the environment? Mar Pollut Bull 104:290-293

Duncan EM, Broderick A, Fuller WJ, Galloway TS, Godfrey MH, Hamann M et al (2018). Microplastic ingestion ubiquitous in marine turtles. Glob Change Biol 25:744-752

Dusaucy J, Gateuille D, Perrette Y, Naffrechoux E (2021) Microplastic pollution of worldwide lakes. Environ Pollut 284:117075

ECCC (2020) Science assessment of plastic pollution. Government of Canada. https://www.canada.ca/en/environment-climate-change/services/evaluating-existingsubstances/science-assessment-plastic-pollution.html. Accessed 14 November 2021

Felismino MEL, Helm PA, Rochman CM (2021) Microplastic and other anthropogenic microplastics in water and sediments of Lake Simcoe. J Great Lakes Res 47:180-189

Girard RE, Clark BJ, Yan ND, Reid RA, David SM, Ingram RG, Findeis JG (2007) History of chemical, physical and biological methods, sample locations and lake morphometry for the Dorset Environmental Science Centre (1973 - 2006). Ont. Min. Envir. Technical Report 2007

Gomes T, Bour A, Coutris C, Almedia AC, Bråte IL, Wolf R, et al. (2021) Ecotoxicology impacts of microand nanoplastics in terrestrial and aquatic environments. In Banks MS (ed) Microplastic in the environment: Pattern and process, Environmental contamination remediation and management, Springer, Cham, Switzerland, https://doi.org/10.1007/978-3-030-78627-4 7

Grbić J, Helm P, Athey S, Rochman CM (2020) Microplastics entering northwestern Lake Ontario are diverse and linked to urban sources. Water Res 174:115623

Hall RI, Smol JP (1996). Paleolimnological assessment of long-term water-quality changes in southcentral Ontario lakes affected by cottage development and acidification. Can J Fish Aquat Sci 53:117

Hammer $\varnothing$, Harper DAT, Ryan PD (2001) PAST: Paleontological Statistics Software Package for Education and Data Analysis. Palaeontologia Electronica 4(1): 9p

Hidalgo-Ruz V, Gutow L, Thompson RC, Thiel M (2012) Microplastics in the marine environment: A review of the methods used for identification and quantification. Environ Sci Technol 46:30603075

Hirai H, Takada H, Ogata Y, Yamashita R, Mizukawa K, Saha M et al (2011) Organic micropollutants in marine plastics debris from the open ocean and remote and urban beaches. Mar Pollut Bull 62:1683-1692

Hoellein TJ, Rochman CM (2021) The "plastic cycle": A watershed-scale model of plastic pools and fluxes. Front in Ecol Environ 19:176-183

Kallenbach EMF, Rødland ES, Buenaventura NT, Hurley R (2022) Microplastics in terrestrial and freshwater environments. In Banks MS (ed) Microplastic in the environment: Pattern and process, Environmental contamination remediation and management, Springer, Cham, Switzerland, https://doi.org/10.1007/978-3-030-78627-4_4 
Lebreton L, Slat B, Ferrari F, Sainte-Rose B, Aitken J, Marthouse R et al (2018) Evidence that the Great Pacific Garbage Patch is rapidly accumulating plastic. Nature 8:4666

Lenaker PL, Baldwin AK, Corsi SR, Mason SA, Reneau PC, Scott JW (2019) Vertical distribution of microplastics in the water column and surficial sediment from the Milwaukee River Basin to Lake Michigan. Environ Sci Technol 53:12227-12237

Li J, Liu H, Chen P (2018) Microplastics in freshwater systems: A review on occurrence, environmental effects, and methods for microplastics detection. Water Res 137:362-374

Loppi S, Roblin B, Paoli L, Aherne J (2021) Accumulation of airborne microplastics in lichens from a landfill dumping site (Italy). Sci Rep 11:4564

Mato Y, Isobe T, Takada H, Kanehiro H, Ohtake C, Kaminuma T (2001) Plastic resin pellets as a transport medium for toxic chemicals in the marine environment. Environ Sci Technol 35:318-324

Mills RB, Paterson AM, Blais JM, Lean DRS, Smol JP, Mierle G (2009) Factors influencing the achievement of steady state in mercury contamination among lakes and catchments of south-central Ontario. $\mathrm{C}$ J Fish Aquat Sci 66:187-200

Napper IE, Davies BFR, Clifford H, Elvin S, Koldewey HJ, Mayewski PA, et al (2020) Reaching new heights in plastic pollution - preliminary findings of microplastics on Mount Everest. One Earth 3:621-630

Nürnberg GK, Fischer R, Paterson AM (2018) Reduced phosphorous retention by anoxic bottom sediments after the remediation of an industrial acidified lake area: Indications from $\mathrm{P}, \mathrm{Al}$, and Fe sediment fractions. Sci Total Environ 626:412-422

Remy F, Collard F, Gilbert B, Compère P, Eppe G, Lepoint G (2015) When microplastic is not plastic: The ingestion of artificial cellulose fibers by macrofauna living in seagrass macrophytodetritus. Environ Sci Technol 49:11158-11166

Roblin B, Aherne J (2020) Moss as a biomonitor for the atmospheric deposition of anthropogenic microfibres. Sci Total Environ 715: 136973

Roblin B, Ryan M, Vreugdenhil A, Aherne J (2020) Ambient atmospheric deposition of anthropogenic microfibers and microplastics on the western periphery of Europe (Ireland). Environ Sci Technol. 54:11100-11108

Rochman CM, Hentschel BT, Teh SJ (2014) Long-term sorption of metals is similar among plastic types: Implications for plastic debris in aquatic environments. PLOS ONE 9:1-10

Sa LC, Oliveira M, Ribeiro F, Rocha TL, Futter MN (2018) Studies of the effects of microplastics on aquatic organisms: What do we know and where should we focus our efforts in the future? Sci Total Environ 645:1029-1039

Scheider WA, Snyder WR, Clark B (1979) Deposition of nutrients and major ions by precipitation in south-central Ontario. Metrics 12:171-185

Sussarellu R, Suquet M, Thomas Y, Lambert C, Fabioux C, Pernet MEJ et al (2016) Oyster reproduction is affected by exposure to polystyrene microplastics. PNAS 113:2430-2435 
473 Tamminga M, Fischer EK (2020) Microplastics in a deep, dimictic lake of the North German Plain with

$474 \quad$ special regard to vertical distribution patterns. Environ Pollut 267:115507

475 Triebskorn R, Braunbeck T, Grummt T, Hanslik L, Huppertsberg S, Jekel M et al (2019) Relevance of nano$476 \quad$ and microplastics for freshwater ecosystems: A critical review. TrAC - Trend Anal Chem 110:375-

$477 \quad 392$

478 Turner S, Horton AA, Rose NL, Hall C (2019) A temporal sediment record of microplastics in an urban $479 \quad$ lake, London, UK. J Paleolimnology 61:449-462

480 Welsh B (2022) Anthropogenic particles and microplastics in headwater lake catchments in Muskoka481 Haliburton, Canada. Thesis, Trent University

482 Wong AHK, McQueen DJ, Williams DD, Demers E (1997) Transfer of mercury from benthic invertebrates 483 to fishes in lakes with contrasting fish community structures. Can J Fish Aquat Sci 54:1320-1330

484 Wright SL, Thompson RC, Galloway TS (2013) The physical impacts of microplastics on marine organisms: $485 \quad$ A review. Environ Pollut 178:483-492

486 Wright SL, Ulke J, Font A, Chan KLA, Kelly FJ (2020) Atmospheric microplastic deposition in an urban 487 environment and evaluation of transport. Environ Int 156:105411

488 Yao H, Deveau M, Scott L (2009) Hydrological data for lakes and catchments in Muskoka-Haliburton 489 (1978-2007). Ont. Min. Envir. Data Report DR 09/1 
490 Statements and Declaration

491 Funding

492 This research was carried out with the support from ECO Canada Co-op Student Work Placement program 493 and an NSERC CGS-M scholarship to Brittany Welsh.

494 Competing Interests

495 The authors declare no competing financial or personal interests

496 Author Contribution

497 Brittany Welsh: Study design, particle extractions and identification, microscopy, interpretation 498 of data, writing - original draft

499 Julian Aherne: Study design, interpretation of data, writing - original draft

500 Andrew M. Paterson: Study design, interpretation of data, writing - review and editing

501

502 Huaxia Yao: Supported field sampling, provided background information on study sites, writing

503

504 - review and editing

Chris McConnell: Supported field sampling, provided background information on study sites, writing - review and editing 
Table 1 Physical characteristics for the 14 study lakes in Muskoka-Haliburton, Canada including: location (UTM Zone 17), type of samples collected ( W = lake water, $\mathrm{S}=$ lake sediment, $\mathrm{D}=$ depth stratification, $\mathrm{T}=$ Temporal samples), number of shoreline residences on the lake, lake area (ha), watershed area (ha), lake volume $\left(10^{4} \mathrm{~m}^{3}\right)$, mean and max depth (Hall and Smol 1996; Girard et al. 2007; Nürnberg et al. 2018; Wong et al. 1997)

\begin{tabular}{|c|c|c|c|c|c|c|c|c|c|c|c|c|}
\hline \multirow[t]{2}{*}{ Lake } & \multirow{2}{*}{$\begin{array}{c}\text { Easting } \\
\text { (m) }\end{array}$} & \multirow{2}{*}{$\begin{array}{l}\text { Northing } \\
\text { (m) }\end{array}$} & \multicolumn{4}{|c|}{ Samples } & \multirow{2}{*}{$\begin{array}{c}\text { Number of } \\
\text { Shoreline } \\
\text { Residences }\end{array}$} & \multirow{2}{*}{$\begin{array}{l}\text { Lake } \\
\text { Area } \\
\text { (ha) }\end{array}$} & \multirow{2}{*}{$\begin{array}{c}\text { Watershed } \\
\text { Area (ha) }\end{array}$} & \multirow{2}{*}{$\begin{array}{c}\text { Lake } \\
\text { Volume } \\
\left(10^{4} \mathrm{~m}^{3}\right) \\
\end{array}$} & \multirow{2}{*}{$\begin{array}{c}\text { Mean } \\
\text { Depth }(\mathrm{m})\end{array}$} & \multirow{2}{*}{$\begin{array}{l}\text { Max Depth } \\
\text { (m) }\end{array}$} \\
\hline & & & W & $\mathrm{S}$ & $D$ & $\mathrm{~T}$ & & & & & & \\
\hline Blue Chalk & 661837 & 5007066 & $X$ & & $x$ & $X$ & 11 & 52 & 158 & 447 & 8.5 & 23 \\
\hline Chub & 638398 & 5017348 & $x$ & & $x$ & $x$ & 24 & 34 & 306 & 306 & 8.9 & 27 \\
\hline Crosson & 654512 & 4994145 & & & $x$ & $\mathrm{X}$ & 0 & 57 & 578 & 522 & 9.2 & 25.0 \\
\hline Dickie & 650192 & 5001333 & $x$ & $x$ & $x$ & $x$ & 133 & 94 & 500 & 468 & 5.0 & 12.0 \\
\hline Fawn & 637717 & 5003574 & $\mathrm{X}$ & $x$ & & & 51 & 11 & 1,462 & 300 & 3.5 & 7.9 \\
\hline Harp & 645976 & 5026855 & $x$ & $x$ & $x$ & $\mathrm{X}$ & 96 & 71 & 542 & 949 & 13.3 & 37.5 \\
\hline Heeney & 649092 & 4998918 & $x$ & & & $x$ & 11 & 21 & 93 & 71 & 3.3 & 5.8 \\
\hline Mouse & 669338 & 5005773 & $x$ & $X$ & & & $0^{b}$ & 9 & 185 & 44 & 4.9 & 9.0 \\
\hline Plastic & 671097 & 5005242 & $x$ & $x$ & $x$ & $X$ & 0 & 32 & 128 & 254 & 7.9 & 16.3 \\
\hline Ranger & 668976 & 5001928 & $x$ & $x$ & & & $1^{\mathrm{c}}$ & 86 & 260 & 63 & 5.6 & 13.0 \\
\hline Ridout & 658756 & 5004543 & & & $x$ & & 1 & 47 & 54 & 314 & 6.7 & 20.4 \\
\hline Red Chalk East & 661809 & 5006310 & $x$ & & $x$ & $x$ & 0 & 13 & 589 & 74 & 5.7 & 19.0 \\
\hline Red Chalk Main & 661108 & 5006047 & $x$ & & $x$ & $x$ & 3 & 44 & 589 & 736 & 16.7 & 38 \\
\hline Three Mile $^{\mathrm{a}}$ & 620114 & 5005350 & $x$ & & $x$ & $\mathrm{X}$ & 145 & 230 & 1,320 & 1,549 & 6.7 & 12.0 \\
\hline Young & 613953 & 5006692 & & $x$ & & & 4 & 106 & 502 & 1,274 & 12.0 & 21.1 \\
\hline
\end{tabular}

"Hammell's Bay

${ }^{b}$ There is an abandoned ranger's camp next to the lake

'There is also an abandoned sawmill next to the lake 
512 Table 2 Average concentration of microplastics ( $\mathrm{mp} / \mathrm{L} ; \mathrm{mp} / \mathrm{hr}$ ) in each of the blank samples collected and 513 their coefficient of variation

\begin{tabular}{|c|c|c|}
\hline QA/QC Sample (liquid) & $\begin{array}{c}\text { Average Microplastic } \\
\text { Concentration (mp/L) }\end{array}$ & Coefficient of Variation (\%) \\
\hline Unfiltered B-Pure ( $\mathrm{n}=16)$ & 0.46 & 65 \\
\hline $\begin{array}{c}\text { Unfiltered Deionised (DI) water } \\
(\mathrm{n}=8)\end{array}$ & 0.16 & 90 \\
\hline $\begin{array}{c}\text { Unfiltered } \mathrm{H}_{2} \mathrm{O}_{2}(\mathrm{n}=6) \\
\text { Unfiltered } \mathrm{ZnCl}_{2}(\mathrm{n}=5)\end{array}$ & 1.26 & 64 \\
\hline Lake field blank ( $\mathrm{n}=12)$ & 7.38 & 68 \\
\hline & 0.00 & Coefficient of Variation (\%) \\
\hline & & 83 \\
\hline QA/QC Sample (open-air) & Average Microplastic \\
\hline Oven ( $\mathrm{n}=12)$ & 0.00 & 178 \\
\hline Filtering ( $\mathrm{n}=51)$ & 0.20 & 100 \\
\hline Fume hood ( $\mathrm{n}=11)$ & 0.24 & 78 \\
\hline
\end{tabular}

514 a The average concentration of microplastics in the liquid and air QA/QC samples have been normalized to MP $L^{-1}$ and MP $h r^{-1}$ 515 respectively 
518 Fig. 1 Location of the 14 study lakes in Muskoka-Haliburton, Canada. Inset shows the location of the 14

519 sites in south-central Ontario, Canada

520 Fig. 2 Distribution (histogram and box-plot) in the concentration of microplastics $(\mathrm{mp} / \mathrm{L}$ ) in the lake water 521 samples collected from the study lakes $(n=12)$ in Muskoka-Haliburton, Canada, during May and June 2019.

522 Box-plot: The black line represents the median, the box represents the 25th and 75th percentile and the 523 whiskers represent 1.5 times the interquartile range

524 Fig. 3 Distribution in the concentration of microplastics $(\mathrm{mp} / \mathrm{L})$ identified in lake water samples collected 525 from (a) each of the study lakes ( $n=9$ ) in Muskoka-Haliburton; (b) during each month (May to October) 526 that samples were collected; and (c) May and June 2019 versus May to October 2019. Box-plot: The black 527 line represents the median, the box represents the 25th and 75th percentile and the whiskers represent 5281.5 times the interquartile range. Notation: $B C=B l$ ue Chalk, $C B=C h u b, D E=$ Dickie, $H P=H a r p, H Y=H e e n e y$, 529 PC=Plastic, RCE=Red Chalk East, RCM=Red Chalk Main, $T M=$ Three Mile

530 Fig. 4 Distribution in (a) the concentration of microplastics ( $\mathrm{mp} / \mathrm{L}$ ) observed in the epilimnion, 531 metalimnion and hypolimnion; (b) the volume-weighted average compared with the microplastic concentration and microplastic concentration from samples collected 1-metre below the surface; and (c) the concentration of microplastics (mp/L) in samples collected in August 2019 and August 2020 from the study lakes in Muskoka-Haliburton, Canada

Fig. 5 Distribution in the concentration of microplastics $(\mathrm{mp} / \mathrm{g}$ ) in the top 0-3 cm section and bottom 30$33 \mathrm{~cm}$ section of the sediment cores collected from the study lakes ( $n=7)$ in Muskoka-Haliburton, Canada between June and September 2019 
Fig. 1

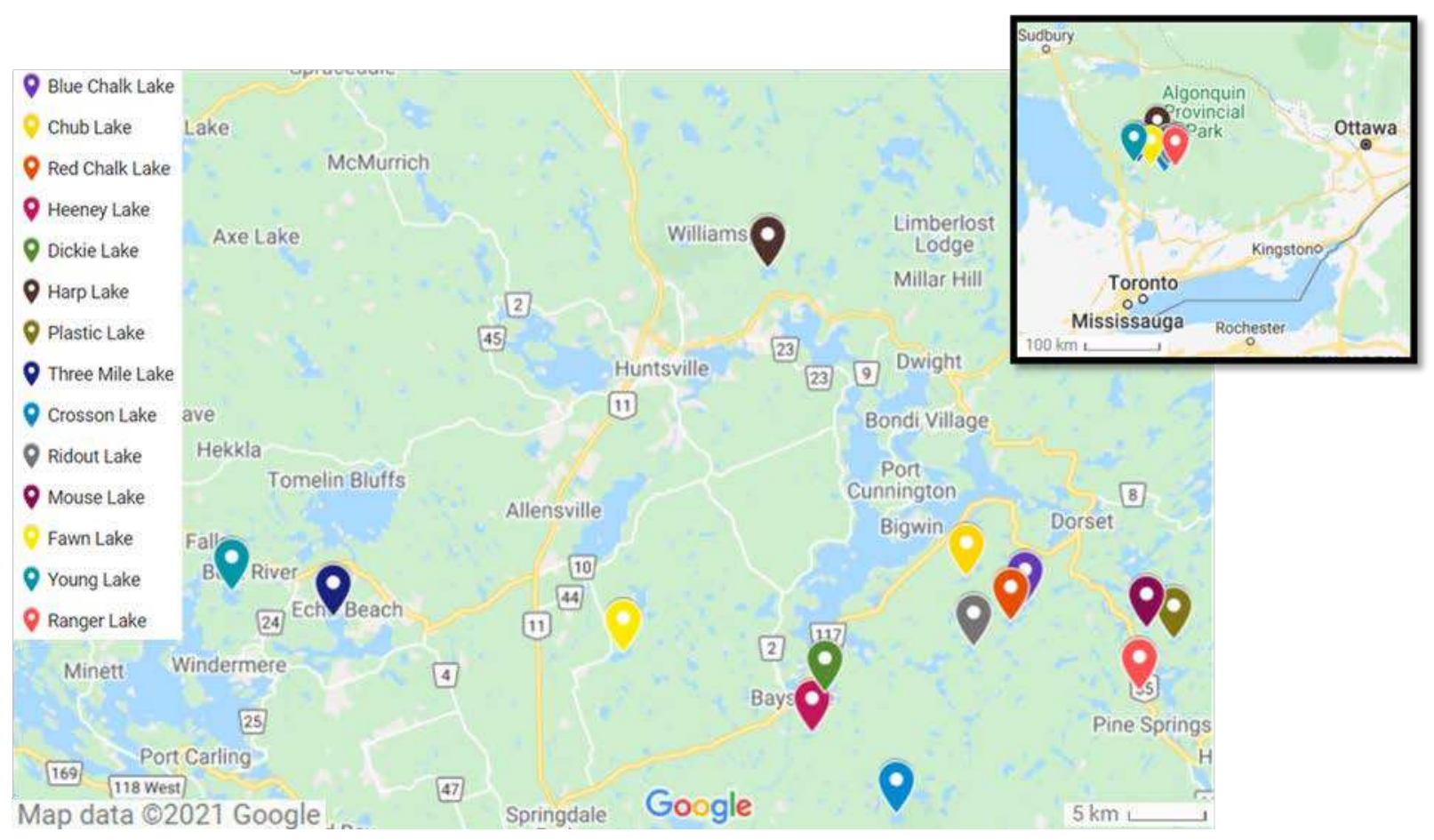


Fig. 2

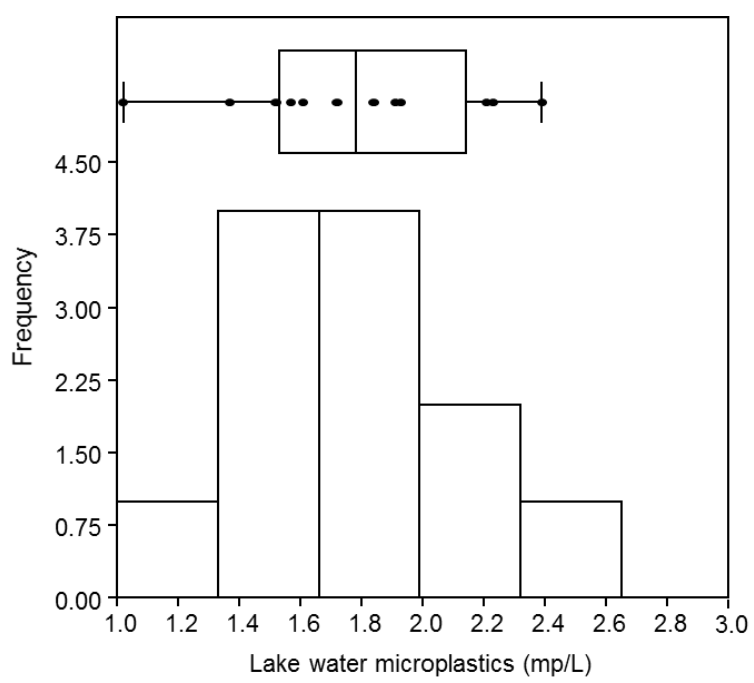

541

542

Fig. 3
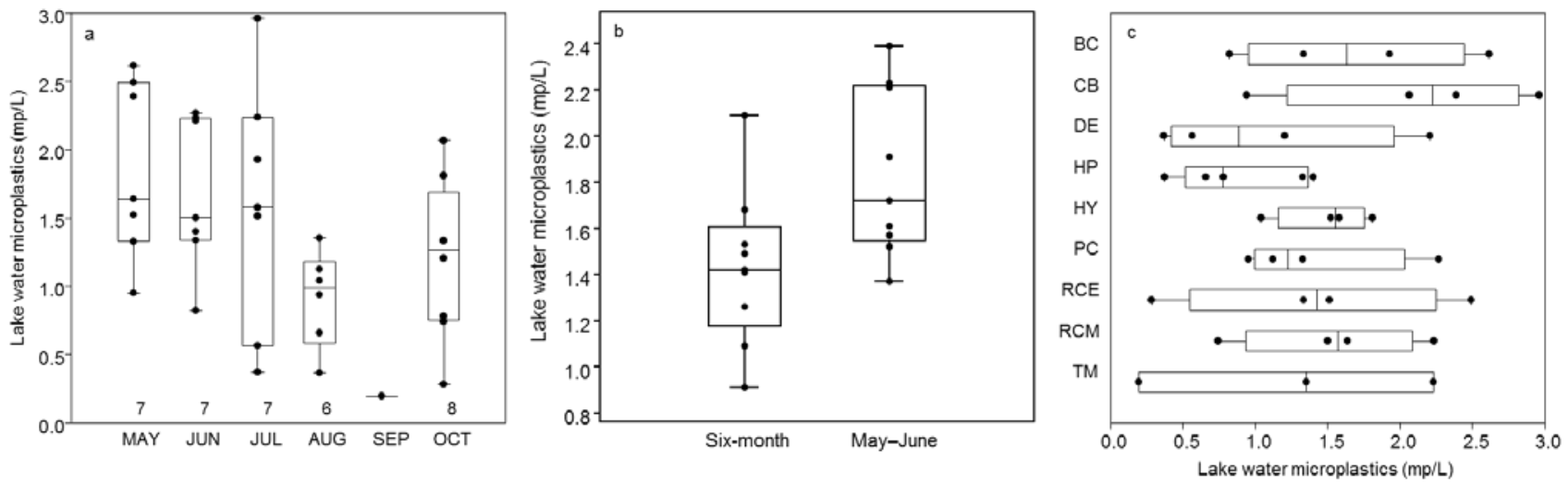

543

$544 \quad$ Fig. 4
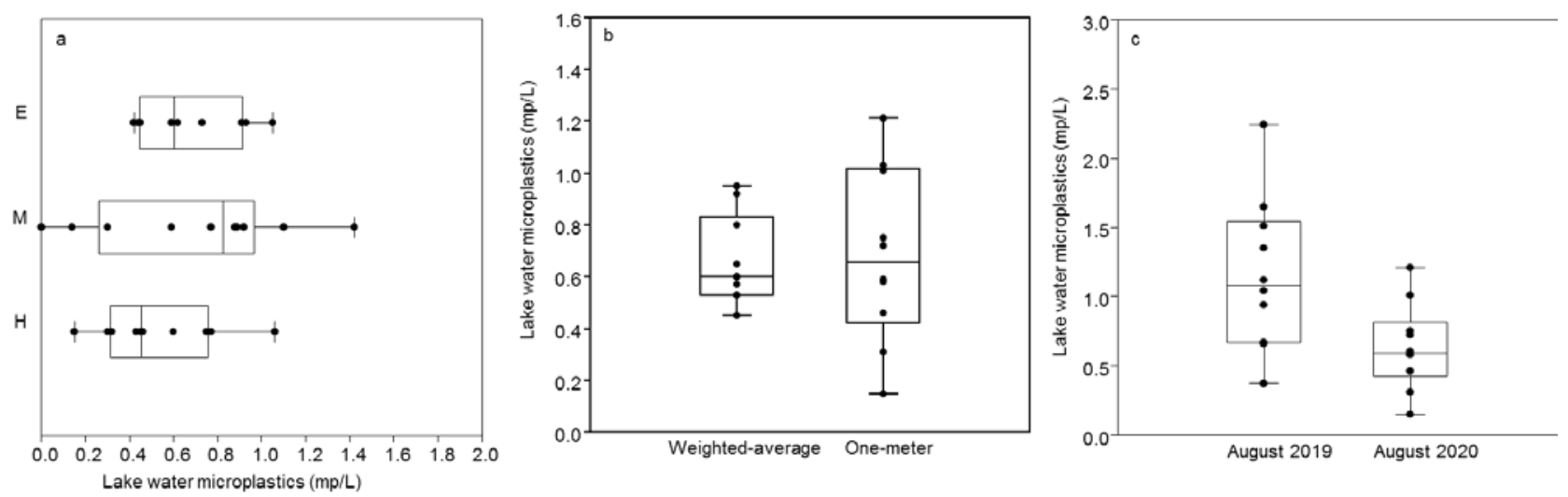
$548 \quad$ Fig. 5

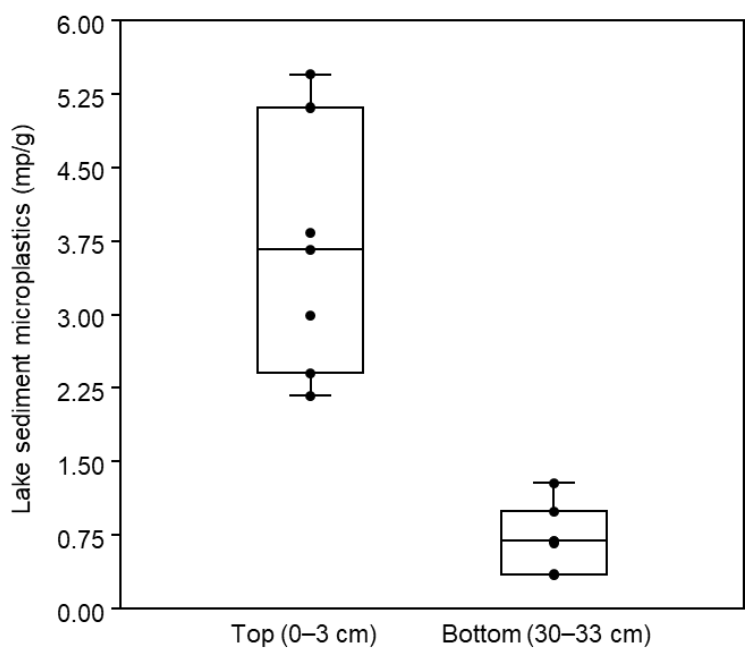

549 


\title{
Supporting Information
}

Microplastics in headwater lake catchments in Muskoka-Haliburton, Canada

\author{
Brittany Welsh ${ }^{a}$, Julian Aherne ${ }^{a}$, Andrew M. Paterson ${ }^{b}$, Huaxia Yao $^{b}$, and Chris McConnell ${ }^{b}$ \\ a School of the Environment, Trent University, Peterborough, Ontario, K9L 0G2, Canada \\ ${ }^{b}$ Ministry of the Environment, Conservation and Parks, Dorset Environmental Science Centre, Dorset, \\ Ontario POA 1E0, Canada \\ Corresponding author*: Brittany Welsh, brittanywelsh@trentu.ca \\ Environmental Earth Sciences
}

\section{Section A}

Fibres were the dominant shape identified in lake water and in the bottom 30-33 cm section of the sediment core with more than $70 \%$ of the identified anthropogenic particles being fibres (Figure SI-1). In the top $0-3 \mathrm{~cm}$ section however, fibres were only slightly more dominant than fragments $(57 \%)$. Across the different lake depths, there was no noticeable difference in the proportion of fibres and fragments across the water column with fibres being relatively evenly distributed (51-67\%). The even distribution of fibres across the water column suggests that the specific density of polymers may be less important for fibres (UNEP 2020).

Anthropogenic particle size ranged from $20 \mu \mathrm{m}$ to 4,990 $\mu \mathrm{m}$ across the study sites, with lake water having the smallest fibre and fragment sizes while lake sediment had the largest (Table SI-1). This suggests that large sized particles have a tendency to sink to the lake bottom while smaller particles remain suspended in the lake. Within the lake sediment, the size of fibres in the $0-3 \mathrm{~cm}$ and $30-33 \mathrm{~cm}$ sections were generally similar; however, the size of fragments in the 30-33 cm section were about 2 times greater than the size of fragments in the $0-3 \mathrm{~cm}$ section. The dominance of smaller particles (fibres and fragments) in the study suggests that particles are likely secondary anthropogenic particles that arose through the weathering and breakdown of large plastic pieces currently in the environment (Kooi and Koelmans 2019).

Across the depth samples, the mean and median anthropogenic particle size generally increased down the water column (Table SI-2). The proportion of anthropogenic particles that had a size less than $400 \mu \mathrm{m}$ also decreased down the water column while the proportion of particles that had a size greater than 1,000 $\mu \mathrm{m}$ increased (Table SI-3a). At a depth of 1-metre and in the epilimnion, approximately $64 \%$ of anthropogenic particles had a size less than $400 \mu \mathrm{m}$ while only $14 \%$ of particles had a size greater than $1,000 \mu \mathrm{m}$ while in the metalimnion and hypolimnion, less than $62 \%$ of particles had a size less than 400 $\mu \mathrm{m}$ and more than $17 \%$ had a size greater than $1,000 \mu \mathrm{m}$. There was also a significant difference in the proportion go anthropogenic. There did not appear to be a difference in the proportion of fragments that fell within each size across the lake depths (Table SI-3b) but for fibres, there was a larger proportion of fibres which had a size less than $400 \mu \mathrm{m}$ in the epilimnion (57\%) and at 1-metre (46\%) whereas there was a larger proportion of fibres that had a size greater than $1,000 \mu \mathrm{m}$ in the metalimnion (33\%) and hypolimnion (43\%; Table SI-3c).

Blue was the most common coloured anthropogenic particle identified across all sample media with more than $72 \%$ of fibres and $60 \%$ of fragments being blue (Table SI-4). White was also commonly identified for fragments (15\%) but was less common for fibres $(0.12 \%)$. White fragments were common in the sediment 
589 samples with $21 \%$ of the fragments identified in the $0-3 \mathrm{~cm}$ section and $52 \%$ in the $30-33 \mathrm{~cm}$ section 590 being white. This could suggest that white fragments are a specific type of polymer that tends to sink or 591 that the fragment lose their colour during the digestion process. Bright eye-catching colours, such as blue, 592 may be more easily recognized during visual identification compared to dull colours and thus 593 overestimated (Hidalgo-Ruz et al. 2012; Dris et al. 2015). Furthermore, transparent or uncoloured 594 microplastics may be easily overlooked as they are harder to identify (Dris et al. 2015). 
595 Fig. SI-1 Proportion of fibres and fragments identified in lake water, sediment (top 0-3cm section and 596 bottom 30-33 cm section) and depth samples (1-metre, epilimnion, metalimnion, and hypolimnion) 597 collected from the study headwater lakes in Muskoka-Haliburton, Canada

598 Table SI-1 The mean and median size $(\mu \mathrm{m})$ as well as the range $(\mu \mathrm{m})$ and coefficient of variation (CV) (\%) 599 for anthropogenic particles (microfibres and fragments combined) microfibres only, and fragments only, 600 collected from atmospheric deposition, lake water, and sediment collected from headwater lakes in 601 Muskoka-Haliburton, Canada

602 Table SI-2 The mean $(\mu \mathrm{m})$, median $(\mu \mathrm{m})$ and range $(\mu \mathrm{m})$ in anthropogenic particles observed in the depth 603 samples collected from the epilimnion, metalimnion, hypolimnion and 1-metre below the surface from 604 each of the study lakes in Muskoka-Haliburton, Canada as well the coefficient of variation (\%)

605 Table SI-3a The proportion (\%) of anthropogenic particles identified in lake water samples collected from 606 the epilimnion, metalimnion, hypolimnion and 1-metre below the surface that fall within each size class

607 Table SI-3b The proportion (\%) of fragments identified in lake water samples collected from the 608 epilimnion, metalimnion, hypolimnion and 1-metre below the surface that fell within in each size class

609 Table SI-3c The proportion (\%) of fibres identified in lake water samples collected from the epilimnion, 610 metalimnion, hypolimnion, and 1-metre below the surface that fell withing in each size class

611 Table SI-4 The proportion (\%) of fibres and fragments and their colour that were identified in lake water 612 and sediment samples $(0-3 \mathrm{~cm}$ and $30-33 \mathrm{~cm}$ sections) collected from the headwater lakes in Muskoka613 Haliburton, Canada 


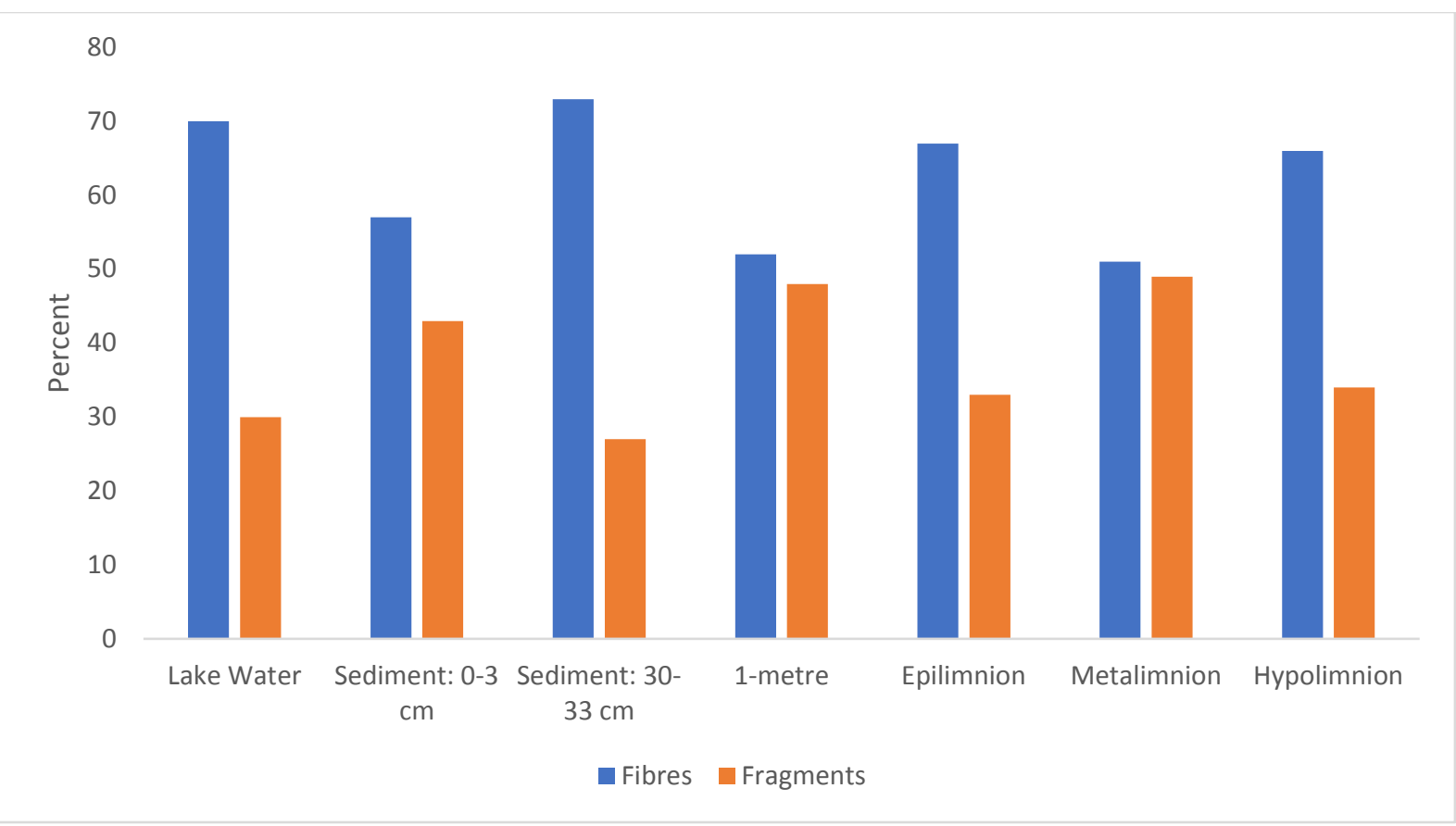

615 Fig SI-1 Proportion of fibres and fragments identified in lake water, sediment (top 0-3cm section and bottom 30-33 cm section) and depth samples (1-metre, epilimnion, metalimnion, and hypolimnion) collected from the study headwater lakes in Muskoka-Haliburton, Canada

Table SI-1 The mean and median size $(\mu \mathrm{m})$ as well as the range $(\mu \mathrm{m})$ and coefficient of variation (CV) (\%) for anthropogenic particles (microfibres and fragments combined) microfibres only, and fragments only, collected from atmospheric deposition, lake water, and sediment collected from headwater lakes in

622 Muskoka-Haliburton, Canada

\begin{tabular}{|c|c|c|c|c|c|c|}
\hline $\begin{array}{c}\text { Sample } \\
\text { Type }\end{array}$ & & $\begin{array}{c}\text { Number of } \\
\text { Particles }\end{array}$ & $\begin{array}{c}\text { Median } \\
(\mu \mathrm{m})\end{array}$ & $\begin{array}{c}\text { Mean } \\
(\mu \mathrm{m})\end{array}$ & $\begin{array}{l}\text { Range } \\
(\mu \mathrm{m})\end{array}$ & $\begin{array}{c}\text { Coefficient } \\
\text { of Variation } \\
\text { (\%) }\end{array}$ \\
\hline Lake Water & $\begin{array}{l}\text { Particles } \\
\text { Fibres } \\
\text { Fragments }\end{array}$ & $\begin{array}{l}882 \\
616 \\
266\end{array}$ & $\begin{array}{c}260 \\
450 \\
60\end{array}$ & $\begin{array}{l}529 \\
700 \\
132\end{array}$ & $\begin{array}{l}20-4,990 \\
20-4,990 \\
20-2,200\end{array}$ & $\begin{array}{l}124 \\
101 \\
158\end{array}$ \\
\hline $\begin{array}{c}\text { Sediment }^{\mathrm{a}} \\
0-3 \mathrm{~cm}\end{array}$ & $\begin{array}{c}\text { Particles } \\
\text { Fibres } \\
\text { Fragments }\end{array}$ & $\begin{array}{c}215 \\
123 \\
92 \\
\end{array}$ & $\begin{array}{l}290 \\
770 \\
160 \\
\end{array}$ & $\begin{array}{c}649 \\
1,035 \\
327 \\
\end{array}$ & $\begin{array}{c}20-4,860 \\
110-4,860 \\
20-4,140\end{array}$ & $\begin{array}{c}127 \\
91 \\
163 \\
\end{array}$ \\
\hline $\begin{array}{l}\text { Sediment }^{a} \\
30-33 \mathrm{~cm}\end{array}$ & $\begin{array}{c}\text { Particles } \\
\text { Fibres } \\
\text { Fragments }\end{array}$ & $\begin{array}{c}170 \\
124 \\
46\end{array}$ & $\begin{array}{l}660 \\
815 \\
310\end{array}$ & $\begin{array}{c}918 \\
1,026 \\
622\end{array}$ & $\begin{array}{c}30-4,890 \\
120-4,890 \\
30-4,850\end{array}$ & $\begin{array}{c}94 \\
81 \\
142\end{array}$ \\
\hline
\end{tabular}




\begin{tabular}{|c|c|c|c|c|c|}
\hline & $\begin{array}{c}\text { Number of } \\
\text { Particles }\end{array}$ & Median $(\boldsymbol{\mu m})$ & Mean $(\boldsymbol{\mu m})$ & Range $(\boldsymbol{\mu m})$ & $\begin{array}{c}\text { Coefficient of } \\
\text { Variation (\%) }\end{array}$ \\
\hline 1-metre & 50 & 210 & 452 & $20-2,770$ & 136 \\
\hline Epilimnion & 45 & 160 & 427 & $40-2,860$ & 147 \\
\hline Metalimnion & 47 & 230 & 443 & $30-2,040$ & 117 \\
\hline Hypolimnion & 35 & 680 & 790 & $50-3,530$ & 98 \\
\hline
\end{tabular}

627

Table SI-3a The proportion (\%) of anthropogenic particles identified in lake water samples collected from 628

\begin{tabular}{|c|c|c|c|c|}
\hline & 1-metre & Epilimnion & Metalimnion & Hypolimnion \\
\hline$<200$ & 46.00 & 60.00 & 46.81 & 28.57 \\
\hline $200-400$ & 18.00 & 11.11 & 14.89 & 14.29 \\
\hline $400-600$ & 12.00 & 8.89 & 12.77 & 5.71 \\
\hline $600-800$ & 6.00 & 4.44 & 6.38 & 14.29 \\
\hline $800-1,000$ & 4.00 & 2.22 & 2.13 & 8.57 \\
\hline$\geq 1,000$ & 14.00 & 13.33 & 17.02 & 28.57 \\
\hline
\end{tabular}

Table SI-3b The proportion (\%) of fragments identified in lake water samples collected from the 630 epilimnion, metalimnion, hypolimnion and 1-metre below the surface that fell within in each size class

\begin{tabular}{|c|c|c|c|c|}
\hline & 1-metre & Epilimnion & Metalimnion & Hypolimnion \\
\hline$<50$ & 41.67 & 20.00 & 34.78 & 0.00 \\
\hline $50-100$ & 16.67 & 40.00 & 17.39 & 25.00 \\
\hline $100-150$ & 16.67 & 20.00 & 17.39 & 33.33 \\
\hline $150-200$ & 4.17 & 0.00 & 8.70 & 16.67 \\
\hline $200-250$ & 4.17 & 6.67 & 0.00 & 8.33 \\
\hline $250-300$ & 0 & 13.33 & 4.35 & 0.00 \\
\hline$\geq 300$ & 16.67 & 0.00 & 17.39 & 16.67 \\
\hline
\end{tabular}

Table SI-3c The proportion (\%) of fibres identified in lake water samples collected from the epilimnion, metalimnion, hypolimnion, and 1-metre below the surface that fell withing in each size class

\begin{tabular}{|c|c|c|c|c|}
\hline & 1-metre & Epilimnion & Metalimnion & Hypolimnion \\
\hline$<200$ & 15.38 & 50.00 & 16.67 & 4.35 \\
\hline $200-400$ & 30.77 & 6.67 & 25.00 & 13.04 \\
\hline $400-600$ & 7.69 & 13.33 & 12.50 & 8.70 \\
\hline $600-800$ & 11.54 & 6.67 & 8.33 & 17.39 \\
\hline $800-1,000$ & 7.69 & 3.33 & 4.17 & 13.04 \\
\hline$\geq 1,000$ & 26.92 & 20.00 & 33.33 & 43.48 \\
\hline
\end{tabular}


Table SI-4 The proportion (\%) of fibres and fragments and their colour that were identified in lake water and sediment samples $(0-3 \mathrm{~cm}$ and $30-33 \mathrm{~cm}$ sections) collected from the headwater lakes in Muskoka-

635 Haliburton, Canada

\begin{tabular}{|c|c|c|}
\hline Colour & Fibre (\%) & Fragment (\%) \\
\hline Black & 6.84 & 0.00 \\
\hline Blue & 72.07 & 59.65 \\
\hline Blue-white & 0.00 & 2.48 \\
\hline Brown & 0.12 & 0.00 \\
\hline Clear & 0.35 & 0.99 \\
\hline Green & 1.51 & 7.92 \\
\hline Grey & 8.00 & 1.49 \\
\hline Orange & 0.23 & 1.24 \\
\hline Pink & 1.97 & 0.50 \\
\hline Purple & 0.70 & 0.00 \\
\hline Red & 8.00 & 8.42 \\
\hline Red-white & 0.00 & 0.50 \\
\hline White & 0.12 & 14.60 \\
\hline Yellow & 0.12 & 2.23 \\
\hline
\end{tabular}

636

637

638

639

640

641

642

643

644

645

646

647

\section{References}

Dris R, Gasperi J, Rocher V, Saad M, Renault N, Tassin B (2015) Microplastic contamination in an urban area: A case study in Greater Paris. Environ Chem 12:592-599

Hidalgo-Ruz V, Gutow L, Thompson RC, Thiel M (2012) Microplastics in the marine environment: A review of the methods used for identification and quantification. Environ Sci Technol 46:30603075

Kooi M, Koelmans AA (2019) Simplifying microplastic via continuous distributions for size, shape and density. Environ Sci and Tech Let. 6:551-557

UNEP. 2020. Monitoring plastics in rivers and lakes: Guidelines for harmonization of methodologies. https://wedocs.unep.org/bitstream/handle/20.500.11822/35405/MPRL.pdf. Accessed 14 November 2021 
Section B:

649 Fig SI-2a Spectra from micro-Raman spectroscopy analyzed through commercial library Open Specy for 650 polyethylene terephthalate microfibre observed in a sample collected from Red Chalk East in Muskoka-

651 Haliburton, Canada

652 Fig SI-2b Spectra from micro-Raman spectroscopy analyzed through commercial library Open Specy for 653 polypropylene fragment observed in the top 0-3 cm section of the sediment core collected from Dickie 654 Lake in Muskoka-Haliburton, Canada

655 Table SI-5 The average concentration $(\mathrm{mp} / \mathrm{L})$ and total number of microplastics identified each of the 656 study lakes in Muskoka-Haliburton, Canada during May-June 2019

657 Table SI-6 The average, range and median concentration of microplastics ( $\mathrm{mp} / \mathrm{L}$ ) in the study lakes in 658 Muskoka-Haliburton, Canada between May and October 2019 as well as the coefficient of variation, 5th 659 and 9th percentile

660 Table SI-7 Concentration of microplastics $(\mathrm{mp} / \mathrm{L})$ identified at each depth in each of the study lakes in 661 Muskoka-Haliburton, Canada (taking into account the percent total volume that each stratum comprises)

662 Table SI-8 The concentration of microplastics $(\mathrm{mp} / \mathrm{L})$ in samples collected 1-metre below the surface in 663 August 2019 and in August 2020 from the study lakes $(n=10)$ in Muskoka-Haliburton, Canada as well as 664 the relative percent difference

665 Table SI-9 Microplastic concentration $(\mathrm{mp} / \mathrm{g}$ ) in the top 0-3 cm section and bottom 30-33 $\mathrm{cm}$ section of 666 the sediment cores collected from seven of the study lakes in Muskoka-Haliburton, Canada between June 667 and September 2019 as well as the microplastic accumulation rate $(\mathrm{mp} / \mathrm{m} 2 /$ day), percent of microplastics 668 buried in the lake sediment and the average microplastic concentration (MP/g) between the 0-3 and 30$66933 \mathrm{~cm}$ section. 


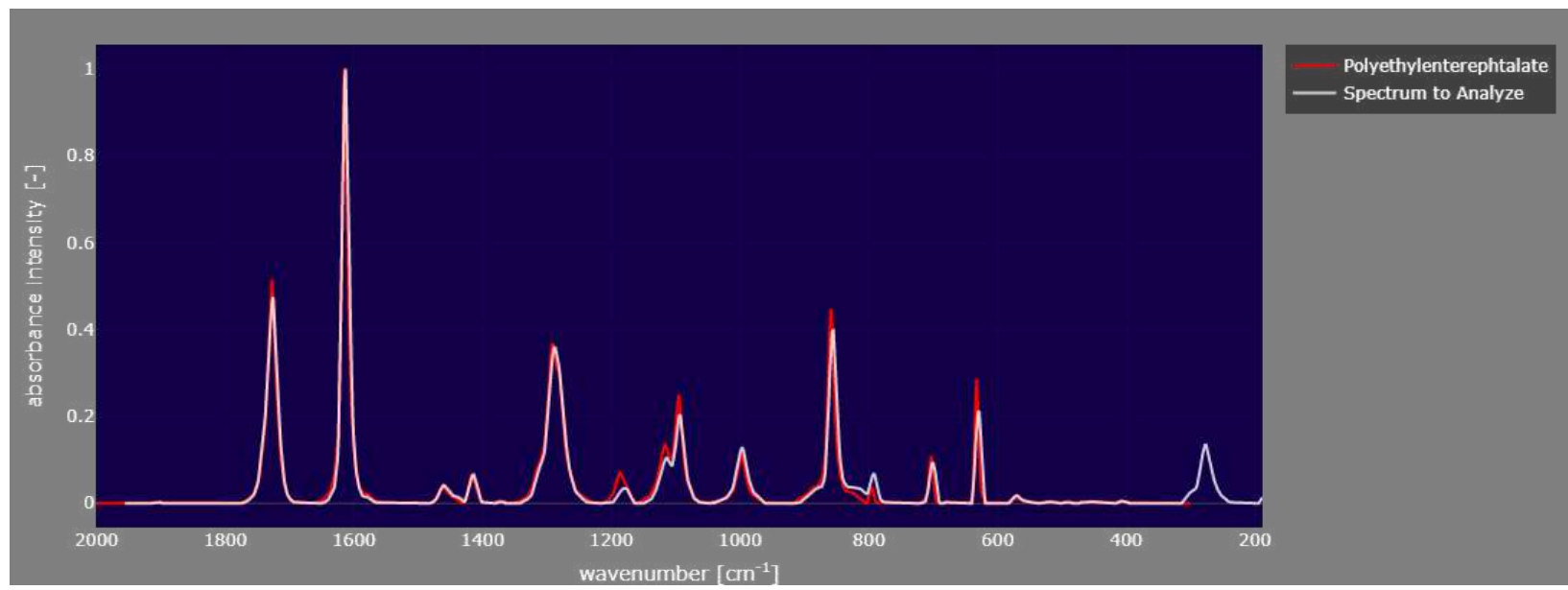

671 Fig SI-2a Spectra from micro-Raman spectroscopy analyzed through commercial library Open Specy for 672 polyethylene terephthalate microfibre observed in a sample collected from Red Chalk East in Muskoka673 Haliburton, Canada

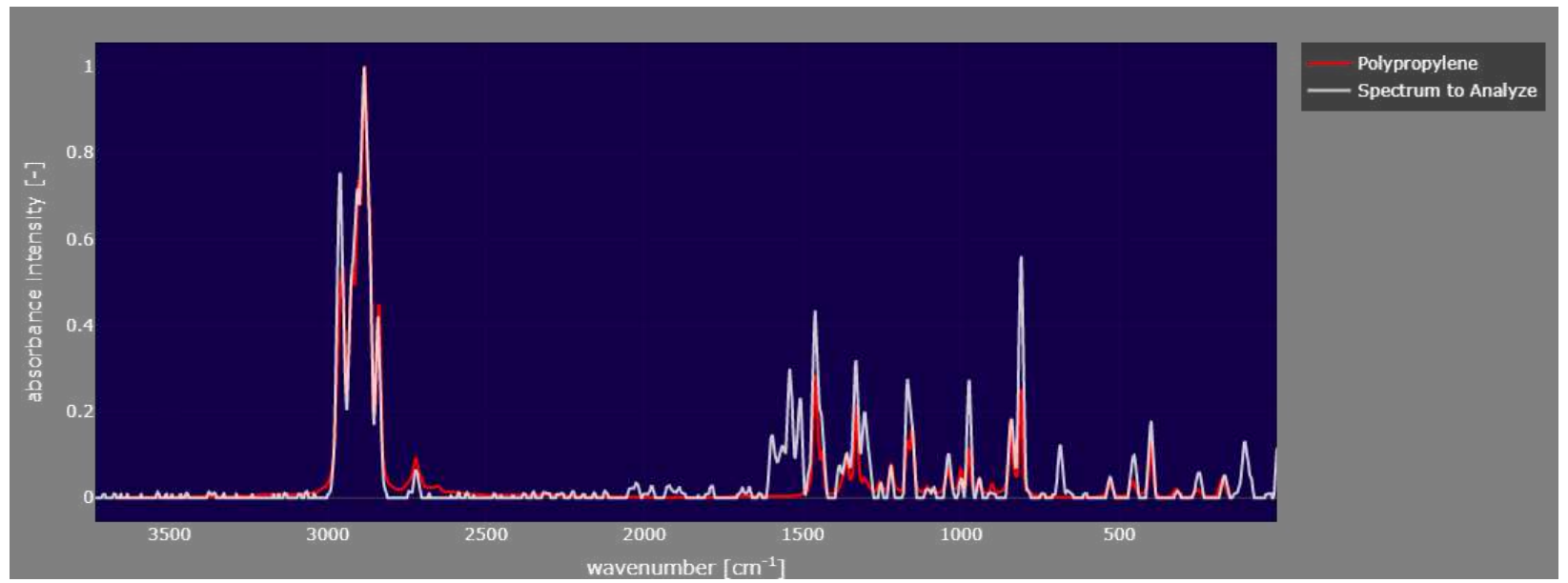

675 Fig SI-2b Spectra from micro-Raman spectroscopy analyzed through commercial library Open Specy for 676 polypropylene fragment observed in the top 0-3 cm section of the sediment core collected from Dickie 677 Lake in Muskoka-Haliburton, Canada 
Table SI-5 The average concentration $(\mathrm{mp} / \mathrm{L})$ and total number of microplastics identified each of the study lakes in Muskoka-Haliburton, Canada during May-June 2019

\begin{tabular}{|c|c|c|}
\hline Lake & Average Concentration (mp/L) & $\begin{array}{c}\text { Total Number of Microplastics } \\
\left(\times 10^{9} \mathrm{MP}\right)\end{array}$ \\
\hline Blue Chalk & 1.72 & 7.68 \\
\hline Chub & 2.39 & 7.27 \\
\hline Dickie & 2.21 & 10.34 \\
\hline Fawn & 1.84 & 5.53 \\
\hline Harp & 1.37 & 12.97 \\
\hline Heeney & 1.52 & 1.07 \\
\hline Mouse & 1.02 & 0.45 \\
\hline Plastic & 1.61 & 4.09 \\
\hline Ranger & 1.93 & 1.22 \\
\hline Red Chalk East & 1.91 & 1.42 \\
\hline Red Chalk Main & 1.57 & 11.56 \\
\hline Three Mile & 2.23 & 34.59 \\
\hline
\end{tabular}

Table SI-6 The average, range and median concentration of microplastics $(\mathrm{mp} / \mathrm{L})$ in the study lakes in Muskoka-Haliburton, Canada between May and October 2019 as well as the coefficient of variation, 5th 682 and 95th percentile

\begin{tabular}{|c|c|c|c|c|c|c|}
\hline Lake & $\begin{array}{c}\text { Average } \\
(\mathbf{m p} / \mathbf{L})\end{array}$ & $\begin{array}{c}\text { Range } \\
\mathbf{( m p / L )}\end{array}$ & $\begin{array}{c}\text { Median } \\
(\mathbf{m p} / \mathbf{L})\end{array}$ & $\begin{array}{c}\mathbf{5}^{\text {th }} \\
\text { Percentile }\end{array}$ & $\begin{array}{c}\mathbf{9 5}^{\text {th }} \\
\text { Percentile }\end{array}$ & $\begin{array}{c}\text { Coefficient } \\
\text { of Variation } \\
(\%)\end{array}$ \\
\hline Blue Chalk & 1.68 & $0.82-2.62$ & 1.63 & 0.90 & 2.51 & 46 \\
\hline Chub & 2.09 & $0.94-2.96$ & 2.23 & 1.11 & 2.88 & 41 \\
\hline Dickie & 1.09 & $0.37-2.21$ & 0.88 & 0.40 & 2.06 & 76 \\
\hline Harp & 0.91 & $0.37-1.40$ & 0.78 & 0.43 & 1.39 & 49 \\
\hline Heeney & 1.49 & $1.04-1.81$ & 1.55 & 1.11 & 1.78 & 22 \\
\hline Plastic & 1.42 & $0.95-2.27$ & 1.23 & 0.98 & 2.13 & 41 \\
\hline $\begin{array}{c}\text { Red Chalk } \\
\text { East }\end{array}$ & 1.41 & $0.28-2.49$ & 1.42 & 0.44 & 2.35 & 64 \\
\hline $\begin{array}{c}\text { Red Chalk } \\
\text { Main }\end{array}$ & 1.53 & $0.74-2.24$ & 1.57 & 0.86 & 2.15 & 40 \\
\hline Three Mile & 1.26 & $0.20-2.23$ & 1.35 & 0.31 & 2.15 & 81 \\
\hline
\end{tabular}


Table SI-7 Concentration of microplastics $(\mathrm{mp} / \mathrm{L}$ ) identified at each depth in each of the study lakes in Muskoka-Haliburton, Canada (taking into account the percent total volume that each stratum comprises)

\begin{tabular}{|c|c|c|c|c|c|c|}
\hline Lake & Epilimnion & Metalimnion & Hypolimnion & $\begin{array}{c}\text { VW } \\
\text { average }\end{array}$ & 1-metre & $\begin{array}{c}\text { Relative } \\
\text { Percent } \\
\text { Difference } \\
\text { (\%) }\end{array}$ \\
\hline Blue Chalk & 1.05 & 0.77 & 0.45 & 0.95 & 1.01 & 7 \\
\hline Chub & 0.45 & 0.92 & 1.06 & 0.60 & 1.21 & 67 \\
\hline Crosson & 0.59 & 0.89 & 0.32 & 0.60 & 0.46 & 26 \\
\hline Dickie & 0.73 & 0.14 & 0.43 & 0.65 & 0.75 & 14 \\
\hline Harp & 0.62 & 0.30 & 0.46 & 0.53 & 0.31 & 53 \\
\hline Plastic & 0.42 & 1.42 & 0.75 & 0.57 & 0.59 & 3 \\
\hline Red Chalk East & 0.59 & 0.00 & 0.15 & 0.53 & 0.58 & 9 \\
\hline Red Chalk Main & 0.93 & 0.88 & 0.60 & 0.80 & 0.72 & 10 \\
\hline Ridout & 0.91 & 1.10 & 0.77 & 0.92 & 1.03 & 11 \\
\hline Three Mile & 0.44 & 0.59 & 0.30 & 0.45 & 0.15 & 101 \\
\hline
\end{tabular}

Table SI-8 The concentration of microplastics $(\mathrm{mp} / \mathrm{L})$ in samples collected 1-metre below the surface in August 2019 and in August 2020 from the study lakes ( $n=10)$ in Muskoka-Haliburton, Canada as well as the relative percent difference

\begin{tabular}{|c|c|c|c|}
\hline Lake & $\begin{array}{c}\mathbf{2 0 1 9} \text { Concentration } \\
\text { (mp/L) }\end{array}$ & $\begin{array}{c}\text { 2020 Concentration } \\
(\mathbf{m p} / \mathbf{L})\end{array}$ & $\begin{array}{c}\text { Relative Percent } \\
\text { Difference (\%) }\end{array}$ \\
\hline Blue Chalk & 1.65 & 1.01 & 48 \\
\hline Chub & 0.94 & 1.21 & 25 \\
\hline Crosson & 0.67 & 0.46 & 37 \\
\hline Dickie & 0.37 & 0.75 & 68 \\
\hline Harp & 0.66 & 0.31 & 72 \\
\hline Heeney & 1.04 & 0.60 & 54 \\
\hline Plastic & 1.12 & 0.58 & 64 \\
\hline Red Chalk East & 1.51 & 0.58 & 89 \\
\hline Red Chalk Main & 2.24 & 0.72 & 103 \\
\hline Three Mile & 1.35 & 0.15 & 160 \\
\hline
\end{tabular}


Table SI-9 Microplastic concentration ( $\mathrm{mp} / \mathrm{g}$ ) in the top 0-3 cm section and bottom $30-33 \mathrm{~cm}$ section of the sediment cores collected from seven of the study lakes in Muskoka-Haliburton, Canada between June and September 2019 as well as the microplastic accumulation rate $(\mathrm{mp} / \mathrm{m} 2 /$ day $)$, percent of microplastics buried in the lake sediment and the average microplastic concentration $(\mathrm{mp} / \mathrm{g})$ between the 0-3 and 30$69433 \mathrm{~cm}$ section

\begin{tabular}{|c|c|c|c|c|c|}
\hline \multirow[t]{2}{*}{ Lake } & \multicolumn{3}{|c|}{ Top 0-3 cm } & \multirow{2}{*}{$\begin{array}{c}\text { Bottom 30-33 } \\
\mathrm{cm}\end{array}$} & \multirow[b]{2}{*}{$\begin{array}{c}\text { Average } \\
0-3 \text { and } \\
30-33 \mathrm{~cm} \\
(\mathrm{mp} / \mathrm{g})\end{array}$} \\
\hline & $\begin{array}{l}\text { Concentration } \\
(\mathrm{mp} / \mathrm{g})\end{array}$ & $\begin{array}{c}\text { Accumulation } \\
\text { Rate } \\
\text { (mp/m²/day) }\end{array}$ & $\begin{array}{c}\text { Percent Burial } \\
\text { (\%) }\end{array}$ & & \\
\hline Dickie & 3.83 & 1.86 & 6.15 & 0.67 & 2.25 \\
\hline Fawn & 2.99 & 1.46 & 1.09 & 0.69 & 1.84 \\
\hline Harp & 5.45 & 2.65 & 5.32 & 0.99 & 3.22 \\
\hline Mouse & 3.66 & 1.78 & 12.99 & 0.34 & 2.00 \\
\hline Plastic & 2.17 & 1.06 & 3.04 & 1.28 & 1.73 \\
\hline Ranger & 5.11 & 2.48 & 63.57 & 0.35 & 2.73 \\
\hline Young & 2.40 & 1.17 & 2.89 & 0.69 & 1.55 \\
\hline
\end{tabular}

